\title{
A Bibliometric Study of Innovation Based on Schumpeter
}

\author{
Fábio Lazzarotti', Michael Samir Dalfovo²,Valmir Emil Hoffmann ${ }^{3}$
}

\begin{abstract}
The aim of this paper is to analyze the production of the scientific innovation theme, based on the Economical Development Theory. The bibliometric study started from the seven categories derived from Schumpeter's seminal text in articles from the following journals IJIM, JOTMI, RAI and RBI, published in the 2000 decade. Results have shown an increase in eleven new categories in the innovation realm, and the predominant categories are the ones that mention 'organizational resources, capabilities and competencies, knowledge and learning'. The topic 'new product', from Schumpeter's original text, was the third most investigated. We have come to the conclusion that the discussion of the subject innovation is far beyond the cases of innovation shown by his seminal author in the early twentieth century and, even though this may not be a theory of resources, this approach and other ones derived from it - such as the dynamic capabilities approach, the skills approach and the organizational knowledge approach - have now attracted the interest of the academy in recent years.
\end{abstract}

Keywords: Innovation; innovation categories; schumpeter; bibliometrics.

\footnotetext{
I Post Graduation in Business Administration Program (under implantation), University of Oeste de Santa Catarina - Rua Getúlio Vargas, 2125, Bairro Flor da Serra. Joaçaba-SC. Cep: 89600-000, 5549 355I-2029, Email: fabio.lazzarotti@unoesc.edu.br

${ }^{2}$ Post Graduation in Business Administration Program, University of Vale do Itajai, Campus A - Rua Patricio Antonio Teixeira 3I7, Bloco 0I, sala 30I. Bairro: Jd Carandaí. Biguaçu-SC. Cep: 88I60-000, 5548 3279-9552,Email: msdalfovo@gmail.com

${ }^{3}$ Post Graduation in Business Administration Program, University of Brasilia, Campus Darcy Ribeiro - Ala Norte, Subsolo, Módulo 25, Brasilia-DF. Cep: 70910-900, 55 6I 3107-6707, Email: ehoffmann@unb.br
} 


\section{Introduction}

Although the possible applicability in different contexts can be seen in the innovation literature (Freeman, 1982a, Moingeon, Lehmann-Ortega, 2006, Öberg, Grundström, 2009, Zheng, Khoury, Grobmeier, 2010), it is in Schumpeter's approach of economic development (1934) that innovation is defined as the formation of new products or services, new processes, raw materials, new markets and new organizations. In all these cases, in order to ensure the concept of new combinations and to be characterized as innovative, it should be taken into account that no one has ever launched something similar or has experienced it, known it or existed.It must be something really unique to the market or the market segment of the firm.

About the conjecture of the current literary contributions on innovation, and considering that the very seminal text of Schumpeter (1934) has opened several possibilities for the existence of innovation, it seems important to identify publications for the monitoring and evolution of classical principles and changes in the expansion of knowledge in the area. Accordingly, one relevant possibility is the bibliometric studies. In the area of innovation, there are several such studies that attempted to identify and quantify indicators that assist in measuring research related to innovation (Cantín, Montenegro, Maturana, 2006, Muñoz, Muñoz, 2006, Crossan, Apaydin, 2010, Durisin, Calabretta, Parmeggiani, 2010). However, there was no bibliometric studies of innovation, in the light of Schumpeter's Theory of Economic Development. Thus, the relevance of this study is grounded in the identification of possible gaps in research, which takes into account the origin of the theoretical approach to innovation formation, such as the one found in Schumpeter's work (1934), pointing to new paths for future research in innovation.

In the academy, publications are available on the journals linked to several Higher Education Institutions (HEls). In this respect, the Coordenação de Aperfeiçoamento de Pessoal de Nível Superior - CAPES (Coordination for Improvement for the Higher Education Personnel) in Brazil has a system that serves as an indicator for Brazilian researchers as fot the quality and visibility of published articles, the Qualis.In a documental research with access to the virtual environment Qualis, four journals were identified in the field of Innovation in the business administration area, base year 2009, bringing the term innovation in the title: International Journal of Innovation Management (IJIM), the Journal of Technology and Management Innovation (JOTMI), the Revista de Administração e Inovação - RAl (Management and Innovation Magazine) and the Revista Brasileira de Inovação RBI - (Brazilian Journal of Innovation). Except IJIM which had its first publications in 1997 the other periodical started their publications in the 2000 decade. Then 2000 to 2009 was the period stabilished for gathering and analysis of the publications. It is known that other publications also present in Qualis may contemplate the subject; however, as the scope of this work is specifically related to the theme of innovation through a bibliometric approach, it is understood that this can best be achieved with this clipping.

Thus, the article aims to analyze the theme of innovation from the scientific publication from the 2000 decade in these four journals, based on the Theory of Economic Development by Schumpeter (1934) in the field of administration. Specifically, we seek to identify the authors and higher HEls publication with the highest rank of publications, as well as the method used in research studies and the object of innovation.

The article is divided into four topics from this introduction.The first topic discusses the theoretical basis that founded the research for the formation of the categories analyzed in the articles directed to innovation. The second topic deals with methodology, which describes the operation of collecting and analyzing data. The third topic introduces and discusses the data on the scientific innovation. Therefore, the fourth topic is intended for final considerations according to the objective of research, the limits and possibilities for future studies. 


\section{Literature Review and Conceptual Background}

Although there have been reports of the use of the term innovation to mean something unusual since the late $1880 \mathrm{~s}$, as in Walker (I888) and Andrews (I890), none of these precursors of innovation studies have been as influential as the economist Joseph Alois Schumpeter. Graduated in Economics, Schumpeter produced articles, essays and dozens of books in the first half of the twentieth century, many of which are still cited and used today in different areas of knowledge, as reported by Rubens Vaz da Costa in the preface to the Brazilian edition of one of major books written by Schumpeter: "Theory of Economic Development: an inquiry into profits, capital, credit, interest rate and the economic cycle" (Schumpeter, 1934). Also, it is in this book that Schumpeter presents one of the first definitions of innovation. This work characterizes the fundamental phenomenon of economic development, associated to innovation and entrepreneurship and having the company as the basis for its studies.

Schumpeter (1934) addresses the entrepreneur as an individual responsible for carrying out new combinations in the economy, and demonstrates his importance for the explanation of economic growth. The entrepreneur, according to the author, is the person who innovates, creating new combinations and changes in the economy's business environment. That is, it is the entrepreneurs who have their own initiative, creating new companies and being largely responsible for maintaining the capitalist economy.

Besides the figure of the entrepreneur and the realization of innovation, Schumpeter (1934) also highlights the importance of credit. Companies that wish to innovate should not finance innovation with financial investment from the previous production. The reallocation of production resources of the circular flow in new combinations is considered a problem, says Schumpeter (1934). Companies should seek credit, which is provided by what Schumpeter called "capitalists" - now known as "venture investers" (Hisrich, Peters, 2004, pp. 26-29).

Regarding the definition of innovation, still according to Schumpeter (1934, p.76), it should cover five cases or areas in the perspective of creating new combinations: (a) introduction of new goods - a new product or service or a new quality of both that no one has launched yet. The novelty is characterized in such a way that can lead the company to implement rehabilitation activities for consumers to familiarize themselves with the new good, (b) introduction of a new method or production process - this is a new way of processing production or marketing products or services that have not yet been tested or experienced by any organization, (c) opening a new market - when the firm develops or creates a new market, where no other company has yet entered, with the area of a particular country in question as a basis, regardless of whether that market has existed or not, (d) acquiring a new source of raw materials or semi-manufactured goods - creating or obtaining a new source of raw material supply for industry and related to the previous case, i.e., no matter this source has been previously established or existed, (e) establishing a new organization of any industry - this case generally involves creating a new business or a new market structure which is characterized by a certain uniqueness of the firm - a monopoly - given the position it may occupy with the new organization.

Tidd, Bessant and Pavitt (2008, p.30), however, instead of five cases of innovation, believe that innovation can take four forms, which are close to those earlier described by Schumpeter (1934): (a) product innovation - changing things (products / services) that a company offers, (b) process innovation - changes in the way products / services are created and delivered, (c) position of innovation - changes in the context in which product / services are introduced, (d) paradigm innovation - changes in the underlying mental models that guide what the company does. The line that divides one type of innovation from the other is tenuous, according to Tidd, Bessant and Pavitt (2008). Sometimes it is difficult to assert that a particular innovation has taken place only in the product, or process, or any of the other forms.

In addition to the definitions, Tidd, Bessant and Pavitt (2008) also emphasize that innovation can be divided into dimensions, according to the degree of novelty involved. If innovation takes place only through improving the performance of components or processes, and novelty only for the company, we have incremental innovation. On the other hand, if there is a significant or advanced change, for example, the creation of a component that is also new to the market, the authors call it radical innovation. This same sort of innovation - incremental and radical - is worked out by other authors such as 
Damanpour (1996), Leifer, O'Connor and Rice (2002), Cantú and Zapata (2006) and Forsman (2009).

However, the original concept of innovation by Schumpeter (1934) does not deal with this classification - incremental and radical. For the author, innovation, as highlighted earlier, is something that nobody has done before and that is, essentially, new to the market. Therefore, within the concept of innovation presented by Schumpeter (1934), incremental innovation does not seem to exist. Based on his concept, the focus is on radical innovation.

Various definitions of innovation can be found in the specialized literature. Most authors present concepts of innovation, highlighting elements that they considered to be most relevant (Cantú, Zapata, 2006). In search of greater conceptual uniformity as well as understanding of innovative processes and standardization in the use of data on innovative activities of industry, the Organization for Economic Cooperation and Development - OECD created the Oslo Manual, which carries both the concepts and classifications, and a set of guidelines and policies for the measurement of innovation in the international arena.

According to the Manual (OECD, 2005, p.55), innovation is either the "implementation of a new significantly improved product (goods or services) or process, or a new marketing method, or a new organizational method in business practices, local workplace organization or external relations. "In general, the Oslo Manual identifies four types of innovations: (a) product innovation, (b) process innovations, (c) organizational innovations, and (d) marketing innovations. This classification seems to address some of Schumpeter's ideas, with only the innovation of input supply missing.

Product innovations, as recommended by the Manual (OECD, 2005), are preceded by substantial changes in the characteristics and / or composition of the products or services. Process innovations refer to significant changes in the method of production or distribution. Organisational innovations are related to the creation and development of new organizational forms, as well as changes in business practice in internal and external environments of the company. And as for marketing innovations, these are changes in product design, packaging and more specifically, the establishment of new pricing methods and creation of new markets.(OECD, 2005).
Some definitions of innovation are strongly linked to technology and, sometimes, even the terms 'innovation' and 'technology' are used interchangeably (Rogers, 2003). However, innovation can be distinguished from 'technological innovation', as it is possible to design different applications of innovation - organizational innovation, social innovation, economic innovation, technological innovation, strategic innovation - taking into account the innovation process and the different areas of an organization (Freeman, 1982a, Cantú, Zapata, 2006, Hernández, 2009).

Some authors believe that technological innovation is the one based on industrial application of scientific and / or technological knowledge. More specifically, Cantú and Zapata (2006) report that innovation is used to describe the introduction and spread of new products, processes or improvement in the company, while technological innovation should be linked to advances in knowledge. Pellissier (2008) redefines the innovation as a result got from the interrelation of three elements (I) Technology (Human Knowledge); (2) Creativity and entrepreneurship; and (3) research (as planned knowledge). However, the Oslo Manual (OECD, 2005) - in its third edition, specifically - explains that technological innovation relates to product and process, an this was the way the issue was addressed in previous editions of the Manual.In this edition, the Manual includes a "non-technological" discussion in reference to organizational and marketing innovations, which refers to the types of innovation mentioned by Schumpeter (1934) in the beginning of the twentieth century.

According to Christensen, Anthony and Roth (2007), innovation is best explained by three theories. According to the author, the innovation process is complex and its theories help to better understand the application of innovation. These are the theories of disruptive innovation, resources, processes and values, and the evolution of the value chain.

Christensen, Anthony and Roth (2007) sees the theory of disruptive innovation as simple, inexpensive, but yet revolutionary. It refers to companies that have managed to create innovations with these characteristics to compete and beat the competition. Disruptive innovations propose a new value by creating new markets as well as suggesting the reformulation of existing ones. The theory of resources, processes and values, in turn, explains why existing companies consolidated in the market struggle 
to cope with disruptive innovation from new companies. However, the theory of evolution of the value chain means developing a new product that requires the performance of a set of activities in an integrated manner. The integration gives the company greater control and especially a broader view of the whole, allowing it to interact with every part of the product architecture, unlike the specialized companies that, as Christensen, Anthony and Roth (2007) points out, only focus on the chain value of a product or service.

However, in the theories presented and discussed by Christensen, Anthony and Roth (2007), there is a relationship similar to what Schumpeter (1942) and Penrose (1959) developed.Especially on the disruptive theory, Schumpeter (1942, Pp.108-136) addresses the theory of "creative destruction", which forecasts the replacement of old products and the habit to consume new ones, what in general results in disruption or discontinuity which conceive a new market.Penrose (1959) states that the combination of available resources of the company is crucial for the entrepreneur to develop new business, which also comes into existence as Christensen, Anthony and Roth's resource theory (2007).

It is understood that many concepts of innovation, although extended and expanded to other areas of knowledge, are sometimes neologisms and concepts derived from studies by other authors, especially in the early writings of Schumpeter (1934, 1942). Nevertheless, studies that built evolutionary models to explain economic development and industry dynamics are highlighted, based on new technologies (Nelson, Winter, 1982, Freeman, 1982b, Dosi, 1984). These studies and authors sought to develop a theoretical framework for the change in economy and represent the current 'neo-schumpeterian' line.However, due to space issues and delineation of the article around Schumpeter's seminal work (1934), the "neo-Schumpeterian" theory line will not be deepened.

\section{Method}

This work can be classified as descriptive, quantitative and documental with the bibliometrics technique. Bibliometrics has been mainly applied to the metric of citations and research groups in different areas of knowledge. Some papers that used this technique were those of Chung and Cox (1990) which determined that $62,2 \%$ of authors had published only once, similar to O'Leary's (2007). McMillan and Casey (2007), when investigating the theoretical framework used in the work of a journal, found that they have changed over time. In Brazil, the studies used bibliometrics in a sometimes similar way, but at other times distinctly. Mendonça et al. (2006) investigated the distribution, methodological characteristics, evolution, theme, and publication productivity of accounting; they presented their results using frequency and figures. The use of descriptive statistics was also the analysis strategy employed by Moretti and Figueiredo (2007), studying the theoretical basis used in the field of corporate social responsibility.

The data source was defined based on three criteria: (I) journals with Qualis classification for the evaluation system of the Coordination of Improvement of Higher Education Personnel (CAPES) in the area of administration, with article publications from the 2000. Our decision about this classification was based on the fact that Qualis is a public classification system created since 1998. Based on experts opinions, with very clear references (like taking part in an international database, for example), and in this sense it is a democratic and open system wich which is reevaluated periodically. The function of Qualis is to support evaluation of Brazilian post-graduate programs as a quality parameter of its cientific production; (2) that the journals presented the central axis of their research on innovation and / or innovation management in a formal way, and even with the term innovation in the title of this journal; (3) and, according to the objective of this study, that the journals had national and / or international coverage.Based on these criteria, we selected the following journals as data sources: International Journal of Innovation Management (IJIM) Journal of Technology Management \& Innovation (JOTMI), Management and Innovation Magazine (RAI) and Journal of Innovation (RBI).

The technique used for the treatment of data was descriptive statistics that Malhotra (2005) suggests as the main objective description of something, usually features or scenarios and content analysis. The analysis procedure 
adopted follows that described by Vergara (2005), which provides a set of relevant steps to the technique of content analysis, with emphasis on: (a) means of data collection, (b) grid and analysis categories; (c) units of analysis.

a) Methods of data collection: the survey data were collected in four articles published in journals classified as Qualis by Capes, via EBSCO system and their journal websites, according to criteria presented earlier. The frequency of the analysed articles, which consider the 2000 decade, approached the following periodical volumes: IJIM, from 1999 to December 2009, covering the v.3, n.I to see 13, n. 4; JOTMI, from 2006 to December 2009 , i.e. from v.l, n.l to v.4, n.4; RAl, from 2004 to December 2009, corresponding to v.l, n.I up the v.6, n.3, and RBI from 2002 to 2009, which considers the v.I, n.I to see v.8, n.2.

b) Grid and analysis categories: The analysis grid is mixed. According to Vergara (2005), the mixed grid comes from previously chosen categories, but allows for the insertion of new ones, as other specific topics that arise during the study.This latter type of analysis, according to the author, is considered suitable for studies which admits the occurrence of new categories in addition to preestablished ones, what assists the verification of subject profiles investigated by researchers of innovation. As for the initial categories of analysis, these were defined based on the Schumpeter's theory (1934), as follows: new goods (products or services); new methods or production process; new markets; new supplies of inputs; new organizatiosn or market structures; loans or financing innovation; and entrepreneur (person who innovates). Some themes were grouped into a single category for its inter-relation or agreement with the theoretical framework. It was also observed that some articles had more than one analysis category in their studies related to innovation. When the integration of two or more categories occurred, we identified the three most evident ones in the article. In the end, the investigation resulted in a total of 18 research topics, and 11 more than in the initial categories in the study.

c) Units of analysis: the titles, abstracts, key words, objectives and methodology of the articles.In each of these units we first studied the occurrence of the term "INNOV" and "INOV". The use of this therm allowed to find the word "innovation" in Portuguese, Spanish and English languages."If this word was not mentioned in any of the units of analysis, the article was dropped from the survey sample because it was understood that innovation was neither the main axis of the studies, nor one of its goals.lt is observed that in some papers the word innovation has been mentioned, sometimes in the introduction, literature review or in other parts of the work. However, there was no development or discussion of the term, but only their use sometime in the text.

Given the goal to check who studied the themes presented in point 'b', and how they were studied, with its quantification, we have defined five other bibliometric analysis: quantitative distribution of authors by number of articles published - without taking into account the position of the author in the work (first, second etc..), but instead the number of participation of each author; ranking of institutions of origin of authors - in case of a single work containing a number of authors from the same institution, it was considered, to calculate this indicator, only one element, the methodology employed in the work established by the classification criteria adopted by Bertero, Vasconcelos and Binder (2003), which provide the following types of methodological approaches: qualitative, quantitative, qualitative and quantitative (quality quantity) and theoretical essays; object of study - according to the classification of Silva (2008): companies or organizations, or industry sector, countries or regions, and individual, (where there was no identification of the objects of study, as in theoretical essays, the name nihil was adopted) and major works referenced - we checked the major papers used by the authors of the articles analyzed by listing the references of each article, with the support of spreadsheet software in Microsoft Office Excel.

\section{Results}

Initially, an overview of articles published in Table $I$ is presented. We can notice that the journals surveyed are recent, considering that the term innovation has been discussed since the early twentieth century, starting mainly with Schumpeter with his first publications in the 1910s (SCHUMPETER, 1934). The oldest magazine is the IJIM, in which 224 items were found. The IJIM was also the only periodical which had $100 \%$ of the articles analyzed at the time, which means all the published articles follow the pattern of the analysis adopted by this study.

The second journal analyzed was JOTMI, which started its publications in 2006. Despite the fact of being the 
most recent periodic analyzed among the four, presented the second greatest number of articles analyzed (I29).We can see a gradual growth of articles with emphasis on innovation, considering the period from 2006 to 2008. In this interval, there was an increase in the number of articles reviewed that investigated innovation as a key objective of the studies. In 2009, however, there was a slight decrease of the studies with this focus.
The RAl, however, was the journal that had the biggest differences in published papers and the analyzed ones. A total of 53 papers did not develop or discuss innovation as a central theme of their studies. This difference may be explained by the fact that RAI has its focus on management and innovation. Accordingly, many articles deal with the areas of administration, but not necessarily from the standpoint of innovation. Furthermore, we realize that the number of articles tracing innovation has grown since the early publications of the magazine in 2004 , as shown in the column of the articles analyzed in Table I.

\begin{tabular}{|ccccccccccc|}
\hline Joumals & \multicolumn{2}{c}{ IJIM } & \multicolumn{2}{c}{ JOTMI } & \multicolumn{2}{c}{ RAI } & \multicolumn{2}{c|}{ RBI } \\
\hline Year & NP & NA & NP & NA & NP & NA & NP & NA & NP & NA \\
\hline 2000 & 22 & 22 & - & - & - & - & - & - & 22 & 22 \\
2001 & 21 & 21 & - & - & - & - & - & - & 21 & 21 \\
2002 & 19 & 19 & - & - & - & - & 09 & 09 & 28 & 28 \\
2003 & 20 & 20 & - & - & - & - & 09 & 08 & 29 & 28 \\
2004 & 20 & 20 & - & - & 12 & 03 & 10 & 09 & 42 & 32 \\
2005 & 20 & 20 & - & - & 16 & 07 & 10 & 10 & 46 & 37 \\
2006 & 20 & 20 & 40 & 27 & 13 & 05 & 10 & 09 & 83 & 61 \\
2007 & 24 & 24 & 45 & 34 & 25 & 13 & 10 & 10 & 104 & 81 \\
2008 & 27 & 27 & 45 & 37 & 27 & 22 & 12 & 12 & 111 & 98 \\
2009 & 31 & 31 & 49 & 31 & 26 & 16 & 12 & 09 & 118 & 87 \\
\hline Total & 224 & 224 & 179 & 129 & 119 & 66 & 82 & 76 & 604 & 495 \\
\hline
\end{tabular}

Table I. Articles published and analyzed by journals and year/ Note: NP = number published NA = number analyzed

The fourth magazine analyzed was the RBI, which had the first works published in 2002. After IJIM, it is the first periodical which presents the biggest number of articles analyzed in comparison to the total number of articles released in the decade. There were only six articles which did not developed the innovation theme.

In an overview of 604 articles published, 495 studies were studied and analyzed with a difference of 109 articles that had other approaches in their studies than the innovation. However, most published articles - over $80 \%$ - presented the adoption of innovation as a major theme of research, which is the predominant feature of the four journals reviewed.

The quantitative distribution of authors who published in the IJIM, JOTMI, RAI and RBI journals are presented in Table 2. According to the test results shown in this table, 940 authors are identified in 495 articles analyzed; however, most published or participated in the publication of only one article, which represents about $90 \%$. This finding departs from the findings by other authors, such as other themes by Chung and Cox (1990) and later O'Leary (2007), which determined that such participation was $2 /$ 3 of their work. Maybe that means an idiosyncrasy among researchers of the topic.

The identification of two articles by author comes next with $8,9 \%$ or 84 occurrences. This number is even smaller when three studies published by the author are examined. Less than $2 \%$ have three published articles focusing on innovation and only three authors had more than four papers during the whole period. We point out the Brazilian 
authors João Amato Neto from Universidade de São Paulo USP (University of São Paulo), José Vitor Martins Bomtempo from Universidade federal do Rio de Janeiro - UFRJ (Federal University of Rio de Janeiro) and Paulo César Negreiros de Figueiredo from Fundação Getúlio Vargas - FGV (Getúlio Vargas Foundation), who had four, five and six jobs respectively. The latter was the only one to be published in three journals, three publications in JOTMI, two in RBI and one in RAI.
In general, the low universe of authors with more than two publications in the reviewed articles seems to indicate that there is a diverse number of researchers studying innovation, which does not concentrate the topic in a few experts. Seen from another perspective, the same number can demonstrate that there is no concern from most researchers in innovation to maintain regular publication, or that adherence to the theme is greater that the constancy in it.

\begin{tabular}{|c|c|c|c|c|c|c|c|c|c|c|}
\hline \multirow{2}{*}{$\begin{array}{l}\text { Journals } \\
\text { No. of authors per paper }\end{array}$} & \multicolumn{2}{|c|}{ IJIM } & \multicolumn{2}{|c|}{ JOTMI } & \multicolumn{2}{|c|}{ RAI } & \multicolumn{2}{|c|}{$\mathrm{RBI}$} & \multicolumn{2}{|c|}{ Total } \\
\hline & NO & $\%$ & NO & $\%$ & NO & $\%$ & NO & $\%$ & $\mathrm{NO}$ & $\%$ \\
\hline Authors with 01 Article & 368 & 89,8 & 231 & 90,9 & 142 & 89,9 & 120 & 87,0 & 836 & 88,9 \\
\hline Authors with 02 articles & 37 & 9,0 & 16 & 6,3 & 16 & 10,1 & 15 & 10,9 & 84 & 8,9 \\
\hline Authors with 03 articles & 05 & 1,2 & 06 & 2,4 & 0 & 0,0 & 03 & 2,2 & 17 & 1,8 \\
\hline Authors with 04 articles & 0 & 0,0 & 01 & 0,4 & 0 & 0,0 & 0 & 0,0 & 01 & 0,1 \\
\hline Authors with 05 articles & 0 & 0,0 & 0 & 0,0 & 0 & 0,0 & 0 & 0,0 & 01 & 0,1 \\
\hline Authors with 06 articles & 0 & 0,0 & 0 & 0,0 & 0 & 0,0 & 0 & 0,0 & 01 & 0,1 \\
\hline Total Authors & 410 & 100 & 254 & 100 & 158 & 100 & 138 & 100 & 940 & 100 \\
\hline
\end{tabular}

Table 2. Quantitative distribution of authors by number of articles published in each journal and total/ Note: NO = number of occurrences $\%=$ percentage of total

Similar to the authors' analysis, we performed a ranking of the institutions with the greatest volume of work.From 163 articles in Table 3, 142 belong to Brazilian institutions, while 21 belong to european institutions. From the cited ones only the Finland Lappeeranta University of Technology which had one publicaton at JOTMI focusing this study. Among the institutions that published the most, we highlight University of São Paulo - USP and the Federal University of Brazil in Rio de Janeiro - UFRJ with 3I (6,3\%) and $29(5,9 \%)$ cases, respectively, the two institutions with the highest rates. When considering only IJIM, the Imperial College London (United Kingdom), Lappeeranta University of Technology (Finland) and Lulea University of Technology (Sweden) has the largest number of publications.

We highlight the reduced presence of Higher Education Institutions (HIEs) in Brazil in international journals, especially in IJIM. UFRJ only had a single article in this
journal.In the case of JOTMI, which is also an international journal but accepted papers in Portuguese, the submission of several studies by authors from Brazil was encouraged. We can see that Brazilian authors do not have the habit of publishing in international journals. The data that demonstrates this perception can be seen in Table 3, given that Brazilian researchers have not published in the journal IJIM except Denise Fleck, UFRJ, who presented a paper.

It is inferred that there is an inclination of researchers to publish in journals that are linked to HEls where they are professors / researchers; this is the case of RAl for the institutions Universidade Nove de Julho - UNINOVE (Unversity Nove de Julho) and USP, which hold approximately $50 \%$ of total publications examined from that journal. This trend, however, can be characterized as endogenous, because knowledge tends to spread more intensively only among the "home" researchers. 


\begin{tabular}{|c|c|c|c|c|c|c|c|c|c|c|}
\hline \multirow{2}{*}{$\begin{array}{c}\text { Journals } \\
\text { Institution and country of origin }\end{array}$} & \multicolumn{2}{|c|}{$\mathrm{IJIM}$} & \multicolumn{2}{|c|}{ JOTMI } & \multicolumn{2}{|c|}{ RAI } & \multicolumn{2}{|c|}{$\mathrm{RBI}$} & \multicolumn{2}{|c|}{ Total } \\
\hline & NO & $\%$ & NO & $\%$ & NO & $\%$ & NO & $\%$ & NO & $\%$ \\
\hline $1^{0}$ The University of Sao Paulo (B razil) & $\overline{0}$ & 0,0 & 10 & 7,8 & 18 & 27,3 & 03 & 3,9 & 31 & 6,3 \\
\hline $2^{\circ}$ The Federal University of Rio de Janeiro (B razil) & 01 & 0,4 & 07 & 5,4 & 03 & 4,5 & 18 & 23,7 & 29 & 5,9 \\
\hline $3^{0}$ Campinas State U niversity ( $\mathrm{B}$ razil) & 0 & 0,0 & 04 & 3,1 & 0 & 0,0 & 11 & 14,5 & 15 & 3,0 \\
\hline University N ove de Julho (Brazil) & 0 & 0,0 & 01 & 0,8 & 13 & 19,7 & 01 & 1,3 & 15 & 3,0 \\
\hline $4^{\circ}$ The $\mathrm{G}$ etbeio $\mathrm{V}$ argas F oundation (B razil) & 0 & 0,0 & 05 & 3,9 & 06 & 9,1 & 02 & 2,6 & 13 & 2,6 \\
\hline $5^{\circ}$ The Federal U niversity of Santa Catarina (B razil) & 0 & 0,0 & 02 & 1,6 & 09 & 13,6 & 01 & 1,3 & 12 & 2,4 \\
\hline $6^{\circ}$ The Federal U niversity of $M$ inas Gerais (B razil) & 0 & 0,0 & 01 & 0,8 & 02 & 3,0 & 06 & 7,9 & 09 & 1,8 \\
\hline $\begin{array}{l}\text { The Federal University of Parana (B razil) } \\
\text { The Federal University of Rio Grande do Sul }\end{array}$ & 0 & 0,0 & 0 & 0,0 & 04 & 6,1 & 05 & 6,6 & 09 & 1,8 \\
\hline (B razil) & 0 & 0,0 & 06 & 4,7 & 02 & 3,0 & 01 & 1,3 & 09 & 1,8 \\
\hline $7^{\circ}$ Imperial College London (United K ingdom) & 07 & 3,1 & 0 & 0,0 & 0 & 0,0 & 0 & 0,0 & 07 & 1,4 \\
\hline L appeeranta U niversity of Technology (Finland) & 06 & 2,7 & 01 & 0,8 & 0 & 0,0 & 0 & 0,0 & 07 & 1,4 \\
\hline Lulea University of Technology (Sweden) & 07 & 3,1 & 0 & 0,0 & 0 & 0,0 & 0 & 0,0 & 07 & 1,4 \\
\hline Total for A rticles among HEIs in Ranking & 21 & 9,4 & 37 & 28,7 & 57 & 86,4 & 48 & 63,2 & 163 & 32,9 \\
\hline Total A nalyzed A rticles & 224 & 100 & 129 & 100 & 66 & 100 & 76 & 100 & 495 & 100 \\
\hline
\end{tabular}

Table 3. Ranking of Institutions with more publications in scientific journals / Note: NO = number of occurrences \% = percentage of total number of articles analyzed Acronysms: Universidade de São Paulo - The University of Sao Paulo (USP), Universidade Federal do Rio Janeiro - The Federal University of Rio de Janeiro (UFRJ), Universidade de Campinas - Campinas State University (UNICAMP) Universidade Nove de Julho - University Nove de Julho- (UNINOVE), Fundação Getúlio Vargas - The Getúlio Vargas Foundation (FGV), Universidade Federal de Santa Catarina - The Federal University of Santa Catarina (UFSC), Universidade Federal de Minas Gerais - The Federal University of Minas Gerais (UFMG), Universidade Federal do Paraná - The Federal University of Parana (UFPR) Universidade Federal do Rio Grande do Sul - The Federal University of Rio Grande do Sul (UFRGS), Imperial College London (United Kingdom), Lappeeranta University of Technology (Finland), Lulea University of Technology (Sweden).

The next set of data is proposed to meet the objective of this study, which is to identify what is being researched by the authors of the articles analyzed in the field of innovation. Starting originally from seven themes, based on Schumpeter's theory of economic development (1934), new themes were added, as described in the methodology. Regarding the first seven issues, we perceive the presence of significant studies on "new products or services" - topic $0 \mathrm{I}$-, being the third most commonly found in articles with 89 (18\%) indications. Research on the launch of new products tends to be a widely discussed topic, considering that the creation of assets is one of the main types of innovation included in Schumpeter's definition (1934). On the other hand, few studies can be seen addressing innovation from the viewpoint of the "new supply of inputs" - theme 07 . Only two papers, or $0,4 \%$, had this type of innovation, which may represent a loophole for construction and expansion of future research.

By adding the percentages of subjects 01 to 07 , it can be seen that IJIM is the magazine that has more articles dealing with the propositions of innovation discussed by Schumpeter (1934), with a total of $49,5 \%$, followed by RAI with $39,3 \%$. The latter result is consistent, since the focus of the magazine is based on that author's theory. The journal that had the lowest incidence of the themes in Schumpeter's theory (1934) was RBI, with $20,9 \%$.

In all journals examined, especially IJIM and RBI, it appears that the highest concentration of articles - 90 (40,2\%) and $23(30,3 \%)$, respectively, was in theme 08 , which addresses the 'resources, abilities and organizational skills; knowledge and learning : The trend of studies on this theme seems to relate to the foundations of theoretical approaches to innovation, as indicated by Schumpeter (1934, 1942), Penrose (1959), Prahalad and Hammel (1990), Rogers (2003) and Christensen, Anthony and Roth (2007), among others. In fact, these studies are also among the most cited in the articles analyzed. We emphasize that this result seems to go back to what has also been studied in strategy. In the study by Furrer, Thomas and Goussevskaia (2008), among the ten most used articles as references in publications of the four major international journals in strategy, five deal with the same topic 08 of this study. Thus, there seems to be convergence among strategy and innovation researchers of the subject. 
The number 09 theme - "innovation management; innovative companies, technological and organizational innovation", was the second one with more proposals for studies, which comprises a total of $30,7 \%$ of cases. Journals RAI, IJIM and JOTMI with 22 (33,3\%), 73 (32,6\%), $4 \mathrm{I}(3 \mathrm{I} .8 \%)$ and cases, respectively, lead the research on this topic. Because of the broad concept of innovation and its relationship with organizations, management, and especially with technology, as heralded by the literature (Freeman, 1982b and Rogers, 2003 and Tidd, Bessant and Pavitt, 2008), we infer that researchers also have a greater inclination to work on innovation considering such factors. Just as theme 8 , the literature reference of topic 09 is among the most cited.

\begin{tabular}{|c|c|c|c|c|c|c|c|c|c|c|}
\hline \multirow{2}{*}{$\begin{array}{l}\text { Journals } \\
\text { Themes }\end{array}$} & \multicolumn{2}{|c|}{ IJIM } & \multicolumn{2}{|c|}{ JOTMI } & \multicolumn{2}{|c|}{ RAI } & \multicolumn{2}{|c|}{$\mathrm{RBI}$} & \multicolumn{2}{|c|}{ Total } \\
\hline & NO & $\%$ & NO & $\%$ & NO & $\%$ & NO & $\%$ & NO & $\%$ \\
\hline 01-N ew goods (products or services) & 60 & 26,8 & 15 & 11,6 & 08 & 12,1 & 06 & 7,9 & 89 & 18,0 \\
\hline 02-N ew M arket & 14 & 6,3 & 11 & 8,5 & 09 & 13,6 & 03 & 3,9 & 37 & 7,5 \\
\hline 03-Entrepreneur (person who innovates) & 16 & 7,1 & 09 & 7,0 & 05 & 7,6 & 0 & 0,0 & 30 & 6,1 \\
\hline 04-N ew method or production process & 11 & 4,9 & 01 & 0,8 & 02 & 3,0 & 02 & 2,6 & 16 & 3,2 \\
\hline 05-N ew organization or market structure & 07 & 3,1 & 01 & 0,8 & 02 & 3,0 & 01 & 1,3 & 11 & 2,2 \\
\hline 06-Credit or financing for innovation & 02 & 0,9 & 02 & 1,6 & 0 & 0,0 & 03 & 3,9 & 07 & 1,4 \\
\hline 07-N ew supply of inputs & 01 & 0,4 & 0 & 0,0 & 0 & 0,0 & 01 & 1,3 & 02 & 0,4 \\
\hline $\begin{array}{l}\text { 08-Resources, abilities and organizational skills, } \\
\text { knowledge and learning }\end{array}$ & 90 & 40,2 & 32 & 24,8 & 16 & 24,2 & 23 & 30,3 & 161 & 32,5 \\
\hline $\begin{array}{l}\text { 09-M anagement of innovation, innovative } \\
\text { companies, technological and organizational } \\
\text { innovation }\end{array}$ & 73 & 32,6 & 41 & 31,8 & 22 & 33,3 & 16 & 21,1 & 152 & 30,7 \\
\hline $\begin{array}{l}10-N \text { etw orks and actors, arrangements and local } \\
\text { productive, innovative systems and clusters, } \\
\text { cooperation agreements and alliances }\end{array}$ & 43 & 19,2 & 13 & 10,1 & 07 & 10,6 & 13 & 17,1 & 76 & 15,4 \\
\hline $\begin{array}{l}\text { 11-Innovation systems, policies and guidelines; } \\
\text { incubators and technological parks }\end{array}$ & 27 & 12,1 & 21 & 16,3 & 04 & 6,1 & 20 & 26,3 & 72 & 14,5 \\
\hline $\begin{array}{l}\text { 12-Strategy, positioning, performance and } \\
\text { competitive advantage }\end{array}$ & 26 & 11,6 & 12 & 9,3 & 07 & 10,6 & 0 & 0,0 & 45 & 9,1 \\
\hline $13-R \& D$ and innovation & 25 & 11,2 & 09 & 7,0 & 0 & 0,0 & 11 & 14,5 & 45 & 9,1 \\
\hline $\begin{array}{l}\text { 14-Theories of economic growth and development, } \\
\text { neo-Schumpeterian and the company's }\end{array}$ & 13 & 5,8 & 10 & 7,8 & 07 & 10,6 & 13 & 17,1 & 43 & 8,7 \\
\hline $\begin{array}{l}\text { 15-T ransfer of knowledge and technology; } \\
\text { relatioship HEIs / STI 's and businesses }\end{array}$ & 09 & 4,0 & 18 & 14,0 & 03 & 4,5 & 07 & 9,2 & 37 & 7,5 \\
\hline 16-Intellectual property and patents & 10 & 4,5 & 06 & 4,7 & 04 & 6,1 & 13 & 17,1 & 33 & 6,7 \\
\hline $\begin{array}{l}17-\text { Scientific and technological production, } \\
\text { bibliometrics and statistics }\end{array}$ & 10 & 4,5 & 04 & 3,1 & 0 & 0,0 & 06 & 7,9 & 20 & 4,0 \\
\hline $\begin{array}{l}\text { 18-0ther (pedagogical innovation, converging } \\
\text { industries, creativity, sustainability, open } \\
\text { innovation) }\end{array}$ & 15 & 6,7 & 20 & 15,5 & 05 & 7,6 & 02 & 2,6 & 42 & 8,5 \\
\hline Total & 224 & 100 & 129 & 100 & 66 & 100 & 76 & 100 & 495 & 100 \\
\hline
\end{tabular}

Table 4. Themes in the articles proposed by the authors to innovation / Note: NO = number of occurrences $\%=$ percentage of total 
Other topics highlighted in studies around innovation are about 'networks and actors, arrangements and local productive and innovative systems and clusters, cooperation agreements and alliances' and 'innovation systems and policies and guidelines; incubators and technological parks' - topics 10 and II with $76(15,4 \%)$ and 72 $(14,5 \%)$ cases, respectively. Such results show the interest of researchers in studying innovation from the perspective of systems and national and / or regional policies, and their development from the concept of networks. In the same study by Furrer, Thomas and Goussevskaia (2008), the theme of alliances, which can also be interpreted as the formation of networks, came in seventh place among the most frequently mentioned keywords.
Regarding the methodology employed, most of the work is of theoretical and empirical nature with $68 \%$ of occurrences $-27,1 \%$ qualitative, and $25,3 \%$ quantitative and 15,6\% combining both methods (Table 5). The theoretical essays, however, had a rate of $32,1 \%$ compared to the total occurrences of the analyzed studies. The RAl journal showed the largest number of occurrences in qualitative studies with $47 \%$ of the 66 articles analyzed, while the RBI stood out in the theoretical essays with a representation of $40,8 \%$ compared to 76 works considered. The JOTMI presented the biggest number of works with the use of the quantitative method with $32,6 \%$ of the 129 analyzed.

\begin{tabular}{|c|c|c|c|c|c|c|c|c|c|c|}
\hline \multirow{2}{*}{$\begin{array}{c}\text { Journals } \\
\text { Methodology }\end{array}$} & \multicolumn{2}{|c|}{$\mathrm{IJIM}$} & \multicolumn{2}{|c|}{ JOTMI } & \multicolumn{2}{|c|}{ RAI } & \multicolumn{2}{|c|}{$\mathrm{RBI}$} & \multicolumn{2}{|c|}{ Total } \\
\hline & NO & $\%$ & NO & $\%$ & NO & $\%$ & NO & $\%$ & NO & $\%$ \\
\hline Qualitative & 60 & 26,8 & $3 C$ & 23,3 & 31 & 47,0 & 13 & 17,1 & 134 & 27,1 \\
\hline Quantitative & 46 & 20,5 & 42 & 32,6 & 20 & 30,3 & 17 & 22,4 & 125 & 25,3 \\
\hline Quali-Quanti & 37 & 16,5 & $2 C$ & 15,5 & 05 & 7,6 & 15 & 19,7 & 77 & 15,6 \\
\hline Theoretical essay & 81 & 36,2 & 37 & 28,7 & 10 & 15,2 & 31 & 40,8 & 159 & 32,1 \\
\hline Total & 224 & 100 & 120 & 100 & 66 & 100 & 76 & 100 & 495 & 100 \\
\hline
\end{tabular}

Table 5. Methodology used in the articles analyzed/ Note: NO = number of occurrences $\%=$ percentage of total

Continuing with the analysis, we found that 'companies I organizations' was the main object of study by researchers with $41,4 \%$ of total global analysis. This result also supports Schumpeter's theory (1934) on innovation, which has the company as a unit of study. When analyzing the journals separately, RBI has the 'industry' as the main object of study with $38,2 \%$ of the sample. Also in relation to the sector, considering the periodic on the whole, it appears that there was a predominance of biotechnology, pharmaceuticals, software, telecommunications and energy sectors as the most searched.Another object of study worked by some articles was the context of countries.In this case, Brazil (mainly), Spain, Taiwan, China and Ireland are the most studied ones. The most significant result of Brazil in relation to other countries is justified by the analysis of the magazines JOTMI, RAI and RBI, mainly the two last ones because they are Brazilians.

Moerover, the object of study 'individual' had a rate of $1,6 \%$ of cases. With this, we can infer that researchers of innovation in the business administration field show concern in studying markets in their contexts in a more general way, and not the individual, as a social subject promoter of innovation. Perhaps this is justified by the existence of several groups of researchers and even journals dealing exclusively with entrepreneurship, which can take the focus from the individual who innovates to other fields. There was also the occurrence of $18,4 \%$ of articles that focused none of the above as objects of study . In general, these are theoretical essays that discuss the characteristics of innovation in the field of theory and not exactly according to the prospect of some company or organization, country or sector.

In relation to the studies cited in the articles analyzed, taking into account the different languages and periods when they were published, the one which presents the largest number of references among all items is the book Managing innovation: the (...) Tidd, J., Bessant, J., Pavitt, K (1997, 200I, 2003, 2005) with 57 occurrences.Next, we have the articles Absorptive capacity: (...) Cohen, WM, Levinthal, DA (1990) and An evolutionary theory 
of Economic Change by Nelson, RR, Winter, SG (1982, $1984,2005)$, as second and third most cited studies with 49 and $4 \mathrm{I}$ cases respectively.In attention to the work of Schumpeter, the two most frequently cited articles are: The Theory of Economic Development (1911, 1912, 1934, 1955, 1961, 1982, 1985, 2006) and Capitalism, Socialism and Democracy $(1942,1950,1975$; 1983, 1984) with 37 and 25 occurrences in order.We highlight the first author's study which was written in the early twentieth century and today is one of the greatest reference books on innovation. When considering only the journals JOTMI, RAI and RBI for analysis purposes, this book would be the first among the most cited.

Websites, manuals and similar documents were not considered for the computation of the references herein. However, we emphasize that the Oslo Manual was one of the most referenced. This handbook, written by the Organization for Economic Cooperation and Development, has served as a standard for most researchers on innovation both in Latin America and Europe, as well as the United States.

\section{Discussion}

This study examined the theme of innovation from recent scientific publications, based on the Theory of Economic Development. The study sought to investigate various aspects of the innovation process, and noted that research in the business administration area on innovation moves toward more innovative activities and, in some ways, surpasses the five cases of innovation presented by Schumpeter (1934) in the early twentieth century. Only in the journals analyzed, at least 17 topics were raised which were studied in relation to innovation. Nonetheless, one of the main themes that composes the definition of innovation - new product or service - remains the subject of research. It is inferred that this predominance may be linked to market dynamics; in other words, a new product or service crystallizes in organizations, often as a marketing strategy perspective, as a power game, in which he who innovates can also earn more.

Of the seven initial categories for analysis reported in the journals, the 'new supply of raw material' was the least investigated. Similarly, other categories such as 'access to finance for innovation', 'establishing a new organization' and 'new production method' also had a low occurrence in the analyzed articles, bearing in mind that these categories derive from Schumpeter's theory (1934). This low incidence of these categories suggests future research to further discussion on innovation in academia or even that maybe they are being treated with other approaches, as may be the case of engineering of materials and / or production and / or finances.

Notwithstanding, the largest number of occurrences of the themes 'resources, abilities and organizational skills, knowledge and learning' and 'innovation management, innovative companies, technological and organizational innovation' have attracted the most interest from researchers in these areas, as well as the expansion of the concept of innovation. It was found that, in many studies, the approach to innovation is discussed from a broad perspective, which involves knowledge, research and development, organizational resources and capabilities, among others. As noted, this theme has been recurrent in the academia, and even that this is not a "theory of resources" [our italics], the approach of other resources and other derivatives, as the dynamic capabilities, skills and even organizational knowledge has now attracted the interest of academia in recent years.

It is demonstrated, therefore, that the discussion of the theme 'innovation' has broken borders and that, in most cases, there is no barrier between one and another kind of innovation. What happens is the relationship of various forms of innovation that are managed within an organizational and market context (FREEMAN, 1982a). Schumpeter's theory (1934) has undoubtedly influenced and still influences the development of research around innovation, according to what was found in this study. However, there are other studies and authors that can also be regarded as references in studies on innovation. This means that the subject is continually expanding, and that perhaps Schumpeter (1934) at the beginning of the twentieth century may not have been able to predict how innovation would occur in the late twentieth and early twenty-first century; nonetheless, he can still be considered an innovator in his time.

The limitations of this study are related to those found in selected journals from the CAPES Qualis system in the area of administration. Therefore, in future studies on the subject, the investigation in other journals that cover larger areas of management, production economics and technology is recommended, in order to compare the results with this article - which may help researchers focus their studies. 


\section{References}

ANDREWS, E.B. (I890). Macvane's political economy. Quarterly Journal of Economics, 4 (3), 33I-339.

BERTERO, C.O.; Vasconcelos, F.C.; Binder, M.P. (2003). Estratégia empresarial: a produção científica (...). Revista de Administração de Empresas. 43 (4), 48-62.

CANTÍN, P.V., Montenegro, I.O., Maturana, V.R., (2006). Vigilancia tecnológica aplicada a nanociencia y nanotecnología en países de latinoamérica. Journal of Technology Management \& Innovation, I (4), 83-94.

CANTÚ, S.O., Zapata, A.R.P., (2006). ¿Qué es la gestión de la innovación y la tecnología (ginnt)? Journal of Technology Management \& Innovation, I (2), 64-82.

CHRISTENSEN, C.M., Anthony, S.D., Roth, E.A. (2007). O futuro da inovação: usando as teorias da inovação para prever mudanças no mercado. Elsevier, Rio de Janeiro.

CHUNG, K. H., Cox, R. A. K. (1990). Patterns of Productivity in the Finance Literature: a study of the bibliometric distributions. Journal of Finance, 45 (I), 30I-309.

CROSSAN, M. M.; Apaydin, M. (2010). A multi-dimensional framework of organizational innovation: a systematic review of the literature. Journal of Management Studies, 47 (6), II54-II9I.

DAMANPOUR, F (1996). Organizational complexity and innovation: developing and testing multiple contingency models. Management Science, 42 (5), 693-716.

DOSI, G. (1984). Technical change and industrial transformation. MacMillan, London.

DURISIN, B.; Calabretta, G.; Parmeggiani, V. (20I0). The intellectual structure of product innovation research: a bibliometric study of the journal of product innovation management, 1984-2004. Journal of Product Innovation Management, 27 (3), 437-45I.

FORSMAN, H. (2009). Balancing capability building for radical and incremental innovations. International Journal of Innovation Management, I3 (4), 50I-520.
FREEMAN, C. (1982a) Innovation and long cycles of economic development. In: SEMINÁRIO INTERNACIONAL. Universidade Estadual de Campinas, Campinas. pP. I-I3.

FREEMAN, C. (1982b) The economics of industrial transformation. Pinter, London.

FURRER, O., Thomas, H., Goussevskaia, A. (2008) The structure and evolution of the strategic management field. International Journal of Management Reviews, I0 (I), I-23.

HERNÁNDEZ, L. M. B. (2009). Una revisión de la interpretación económica sobre la innovación. Journal of Technology Management \& Innovation, 4 (4), I39-I49. HISRICH, R. D., PETERS, M. P. (2004) Empreendedorismo. Bookman, Porto Alegre.

IJIM. International Journal Of Innovation Management. Brighton: World Scientific, 1997-2009. Trimestral. http:// www.worldscinet.com/ijim/ijim.shtml. [Accessed july 10, 2009].

JOTMI. Journal Of Technology Management \& Innovation. Chile: JOTMI Research Group, 2005-2009. Trimestral. http://www.JOTMl.org/index.php/GT. [Accessed february 23, 20I0].

LEIFER, R., O'connor, G. C., Rice, M. (2002). A implementação de inovação radical em empresas maduras. Revista de Administração de Empresas, 42 (2), 17-30.

MALHOTRA, N. K. (2005). Pesquisa de Marketing. Pearson, São Paulo.

McMILLAN, G.St.; Casey, D.L. (2007) Research note: Identifying the invisible colleges of the British Journal of Industrial Relations. British Journal of Industrial Relations, 45 (4), 815-828.

MENDONÇA Neto, O. R.; Riccio, E. L.; Sakata, M. C. G. (2006) Paradigmas de pesquisa em contabilidade no Brasil. In: Encontro Anual da ANPAD, ANPAD, Salvador. pP I-I6. 
MOINGEON, B.; Lehmann-Ortega, L. (2006) Strategic innovation: how to grow in mature markets. European Business Forum, 24, 50-54.

MORETTI, S. L. A.; Figueiredo, J. C. B. (2007) Análise Bibliométrica da Produção sobre Responsabilidade Social das Empresas no ENANPAD. In: Encontro Anual da ANPAD, ANPAD, Rio de Janeiro. Pp. I-16.

MUÑOZ, A.V.; Muñoz, L.R. (2006) Innovación tecnológica forestal, desarrollos y desafios científico tecnológicos en Chile. Journal of Technology Management \& Innovation, I (4), 7I-82.

NELSON, R. R.;Winter, S. G. (1982) An evolutionary theory of economic change. Ballknap Press, Cambridge.

ÖBERG, C.; Grundström, C. (2009) Challenges and opportunities in innovative Firms' network development. International Journal of Innovation Management, I3 (4), 593-613.

O'LEARY, D. E.. (2007) The most cited papers. Human Systems Management, 26 (3), I53-156.

OECD. Organização Para Cooperação E Desenvolvimento Econômico.. (2005) Manual de Oslo: diretrizes para coleta e interpretação de dados sobre inovação. 3.ed. Brasil: Ministério da Ciência e Tecnologia. Financiadora de Estudos e Projetos - FINEP. http://www.finep.gov.br. [Accessed August 0I, 2009].

PENROSE, E. (1959). The Theory of the Growth of the Firm, Wiley, New York.

PELLISSIER, R. (2008). A conceptual framework for the alignment of innovation and technology. Journal of Technology Management \& Innovation, 3 (3), 67-77.

PRAHALAD, C. K.; Hamel, G. (1990) The core competence of the corporation. Harvard Business Review, 90 (3), 79 91.

RBI. Revista Brasileira De Inovação. São Paulo: UNICAMP, 2002-2008. Semestral. ISSN: 1677-2504. http://www.ige. unicamp.br/ojs/index.php/rbi/index. [Accessed March 05, 2010].
RAl. Revista De Administração E Inovação. São Paulo: Uninove, 2004-2009. Quadrimestral. ISSN: 1809-2039. http://www.revista-rai.inf.br/ojs-2.l.l/index.php/rai. [Accessed February 23, 2010].

ROGERS, E. M. (2003). Diffusion of innovations. Free Press. New York.

SCHUMPETER, J.A. (1934). The theory of Economic Development, Harvard University Press, Cambridge, Massachusetts.

SCHUMPETER, J.A.(1942). Capitalism, socialism e democracy. Harper and Row. New York.

SILVA, J.M.P. (2008). O estado-da-arte da literatura em economia e gestão da inovação e tecnologia: um estudo bibliométrico. 77 f. 2008 Tese de Mestrado em Inovação e Empreendedorismo Tecnológico. Faculdade de Engenharia, Universidade do Porto.

TIDD, J., Bessant, J., Pavitt, K. (2008) Gestão da inovação. Bookman. Porto Alegre.

VERGARA, S. C. (2005). Métodos de pesquisa em administração. Atlas. São Paulo.

WALKER, J. (1888) Harvard Law Review, New York.

ZHENG, W.; Khoury, A. E.; Grobmeier, C. (2010). How do leadership and context matter in R\&D team innovation? - A multiple case study. Human Resource Development International, 13 (3), 265-283. 
J. Technol. Manag. Innov. 20II,Volume 6, Issue 4 